\title{
Corán y Literatura apócrifa cristiana: la reelaboración de las figuras de Jesús y María
}

\author{
Pilar González Casado \\ Universidad San Dámaso
}

\begin{abstract}
Resumen: Una línea de la investigación moderna sobre la historia de la formación del Corán lo presenta como una obra literaria propia del contexto de la Antigüedad tardía y no como literatura exclusivamente islámica. La literatura apócrifa cristiana, presente en este contexto, llegó a formar parte del contenido coránico. Esta presencia no fue un mero préstamo literario, sino que el Corán, por medio de recursos estilísticos, re-contextualizó los textos cristianos ofreciendo su propia versión de las figuras de Jesús y María. Esta utilización de la literatura apócrifa cristiana está especialmente presente en las suras 3 y 19 del Corán que relatan la infancia de María, la Anunciación, el nacimiento de Jesús y su infancia.
\end{abstract}

Palabras claves: Islam, Corán, literatura apócrifa, María, recontextualización.

\begin{abstract}
One of the latest arguments of Literary Critics on Koran formation process considers that it is a literary work produced by Late Antiquity Context and it is not possible to consider it as a work produced by islamic literary activity. Christian Apocryphal Literature appeared in this context and became a part of the content of the Koran. The Koran revisited Apocryphal Literature in order to offer an Islamic view about Mary and Jesus. 3th Sura and 19th sura are excelent evidence of this phenomenon.
\end{abstract}

Keywords: Islam, Qur'an, apocryphal literature, Mary, recontextualization.

Fecha de recepción: 4 de mayo de 2019

Fecha de aceptación y versión final: 28 de mayo de 2019

https://doi.org/10.46543/ISID.1928.1003 I ISSN: 1131-7027 I ISSN-e: 2660-7743 


\section{INTRODUCCIÓN}

El Corán y la literatura apócrifa cristiana son dos corpus literarios que, $a$ priori, pueden parecer extraños entre sí, pero que, sin embargo, están estrechamente ligados, como se verá a lo largo de las siguientes páginas. El vínculo existente entre ambos obedece además a un motivo concreto.

Para poder describir la relación existente entre ellos es necesario establecer, en primer lugar, qué entendemos por Corán y qué entendemos por literatura apócrifa desde el punto de vista literario y teológico.

El Corán, tal y como lo presenta la teología musulmana, es una Escritura divina porque procede directamente de Dios. Este la hizo descender hasta el profeta Muhammad (Mahoma), destinatario y transmisor de esta revelación, quien la recibió a través de un intermediario pasivo, Gabriel, el cual no modificó ni su contenido ni su expresión lingüística. En el texto coránico, redactado en primera persona, es Dios quien habla directamente a su interlocutor. Este interlocutor, anónimo, salvo en cuatro ocasiones, se identificó posteriormente con el profeta Muhammad. ${ }^{1}$ La teología islámica posterior, definió este proceso de la revelación del libro o Escritura con el tecnicismo tanzīl - تنزيل-, literalmente, "descenso". El arquetipo coránico es una tabla celestial situada en el trono divino que constituye la pre-imagen eterna del texto descendido. ${ }^{2}$ Durante la controversia

1 Así se interpreta a partir de la sura 85,21-22: “21. ¡Sí es un Corán glorioso, 22. en una Tabla bien guardada!" (las citas en castellano de El Corán están tomadas de Julio CoRTés, El Corán, Barcelona, Herder, 2005). Cf. R. WIsnOsvsKY, "Heavenly Book", en Encyclopaedia of the Qur'ān II, Leiden - Boston, Brill, 2002, 412-413. En cuanto al destinatario anónimo de este mensaje, aparece en las suras 49,3 y 7,158 donde se habla de un «enviado de Dios» o el que se dirige al destinatario anónimo le ordena decir a los hombres que «él es el enviado de Dios», pero sin desvelar su nombre. Otras referencias coránicas al enviado (cf. 4,13; 136,5; 5,11 y 9,62) tampoco emplean el nombre de muhammad para el enviado. La fraseología concreta"Mahoma es el mensajero de Dios", aparece sólo una vez en Corán 48,29. En 3,144 se afirma que "Muhammad no es sino un enviado", al igual que en 3,144 y en 33,40.

2 El término tanzīl (تنزيل) es el nombre de acción del verbo nazzala (نَزَّلَ), descender (cf. Federico Corriente - Ignacio Ferrando, Diccionario avanzado de árabe I, Barcelona, Herder, 2005, 1159). A partir de las suras coránicas que lo contienen $(36,5 ; 41,2 ; 42 ; 56,80$ y 69,43) se identifica con la actividad exclusivamente divina de transmitir un mensaje. Este mensaje descendió oralmente en árabe vernáculo con forma de recitación, tal y como atestigua el término qur'ān (قرآن ) recitación (cf. Arthur JefFerY, The Foreign Vocabulary of the Qur'än, Baroda, Oriental Institute, 1938, 233-234), hasta Muhammad. La tabla celestial que contenía el Corán es la Escritura matriz que la noche del destino descendió de golpe desde Gabriel hasta el profeta. Sin embargo, como Muhammad no lo transmitió de golpe, sino por partes, la exégesis musulmana entiende (según la sura 17,106) que lo fue transmitiendo según las circunstancias propias de cada momento de la revelación. Este argumento dio lugar a un género propio de la exégesis musulmana conocido como asbāb al-nuzül (أسباب النزول), las circunstancias de la revelación, que son recopilaciones de anécdotas que contextualizan las suras coránicas. Las colecciones más prestigiosas son las de Al-Wāḥidī (m. 1075) y Al-Suyūtī (m. 1505) (cf. Richard Bell y Watt Montgomery WATT, Introduction to the Qur'ān, Edinburgh, Edinburgh University Press, 1970, 167). En cuanto a la tabla preservada en el trono divino, lawh mahfüz ( لوح محفوظ; C85,22), es también (según C13,39; 43,4 y 3,7) una Escritura matriz, umm al-kitāb (أم الكتاب ( ). Se trata de una metáfora para expresar el conocimiento y la voluntad divinas que procede de la literatura apócrifa del Antiguo Testamento, tal y como aparece en el Libro 1 de Henoc 47,3; 81,1-2; 93 (cf. Alejandro Diez Macho [dir.], Apócrifos del 
musulmana del siglo Ix acerca de la naturaleza creada o increada del Corán, la metáfora de la tabla celestial alcanzó el rango de dogma y la naturaleza coránica quedó definida como increada. ${ }^{3}$ Esta naturaleza increada tiene importantes repercusiones filológicas. Impide que el texto coránico sea permeable a las circunstancias históricas y al contexto literario en el que descendió. La condición de este descenso niega también la posibilidad de que la composición del corpus coránico obedeciera a un proceso formativo progresivo. Esto supone que hay que entender que el texto coránico en el estado en que se conserva hoy es como descendió sobre Muḥammad entre los años 610 y 632, por lo que la forma textual definitiva del Corán estaría cerrada en la segunda mitad del siglo vII. Como se verá más adelante ${ }^{4}$ los estudios filológicos sobre el proceso formativo del texto coránico cuestionan en algunos aspectos este planteamiento teológico.

La literatura apócrifa es un subconjunto de un conjunto mayor, el de la literatura bíblica, que no solo incluye una serie de textos que tanto el judaísmo como el cristianismo consideran sagrados, sino también textos parabíblicos, es decir, que tienen como referencia la Biblia, ya que sus temas, sus personajes y sus géneros son los mismos, pero no forman parte de su canon. Estos textos fueron recibidos y empleados por ambas religiones, pero los distinguieron cualitativamente de los libros inspirados o revelados que llegaron a formar el canon bíblico. Esta distinción cualitativa consistió en que no los consideraron inspirados, lo que no quiere decir que, en algunos casos, los rechazaran abiertamente y no llegaran a formar parte de la tradición de la Iglesia. En el entorno cristiano, excepto algunos apócrifos cuya canonicidad fue discutida, en general, esta literatura no se consideró inspirada. ${ }^{5}$

Antiguo Testamento IV, Madrid, Cristiandad, 1984; y en El libro de los jubileos 5,13; 16,9 y 32,21; cf. Diez Macho II, Madrid, Cristiandad 1983).

3 A principios del siglo vIII, la escuela teológica de los mu 'tazilíes de corte racionalista definió la naturaleza del Corán como creada. Admitía la existencia del prototipo celestial del Corán, pero negaba su eternidad, porque fue creado en un momento concreto por voluntad divina. La otra escuela teológica del momento, el kalām aš ‘ arī, propugnaba su naturaleza increada. Esta disputa finalizó con la proclamación pública de la naturaleza creada del Corán hecha por el califa AlMa'mūn (813-833). Posteriormente Al-Mutawakkil (847-861) revocó esta doctrina y promulgó la contraria basada en la omnipotencia divina de C16,40 ("Cuando queremos algo, Nos basta decirle: «¡Sé!», y es"). Sobre estas disputas, puede consultarse: Morris S. SEALE, Muslim theology a study of origins with reference to the Church Fathers, London, Luzao and Co. Ltd, 1964; Watt Montgomery WATT, "Early discussions about the Qur'ān", The Muslim World 40 (1950) 21-40 y 96-105; Watt Montgomery WaTT, The formative period of Islamic thought, Edinburgh, Edinburgh Univesity Press, 1973; y Arent Jan WensincK, The Muslim Creed, Cambridge, Cambridge University Press, 1932.

4 V. infra., pp. 31-32.

5 Es muy clarificador un pasaje de la Historia Eclesiástica de Eusebio de Cesarea que contiene una de las primeras tentativas para clasificar los libros aceptados por la Iglesia. Los clasifica en libros recibidos (los cuatro Evangelios, las cartas de Pablo, la primera carta atribuida a Juan, la primera de Pedro y el Apocalipsis de Juan, con cierta reserva); libros discutidos, pero conocidos por muchos (cartas de Santiago y de Judas, segunda de Pedro y segunda y tercera de Juan); inauténticos (los Hechos de Pablo, el Pastor, el Apocalipsis de Pedro, la carta de Bernabé, la Enseñanza de los Apóstoles y el Apocalipsis de Juan) y absurdos e impíos. Menciona que algunos han 
El término griego ảđók@vфos, apócrifo, significa originalmente "escondido" y"secreto" en las obras de los primeros escritores cristianos. Pero el significado de este término ha cambiado sustancialmente desde los inicios del cristianismo, cuando se empleaba para designar los textos secretos de las sectas heréticas, hasta la época actual. ${ }^{6}$ Hoy se sigue empleando para designar a estos escritos heréticos, pero ha perdido su connotación negativa al haberse mostrado su transcendencia en la descripción del proceso de formación del canon del Nuevo Testamento. La crítica literaria actualmente define la literatura apócrifa como aquella en la que se pueden encontrar los tres rasgos siguientes: 1) tratar figuras y acontecimientos relacionados con la historia de la Salvación y el tiempo fundacional del cristianismo; 2) pretender ofrecer un acceso directo y con autoridad a la verdad de la fe por medio de la pseudoepigrafía o pseudonimia o por medio de un narrador omnisciente; y 3) su recepción en una determinada comunidad teniendo en cuenta el contexto y el motivo por el que se compone. ${ }^{7}$ Comprende un arco cronológico muy amplio, desde su nacimiento, alrededor de la segunda mitad del siglo I, hasta el siglo XVI, aunque este límite podría ampliarse hasta el siglo pasado. Trata un amplio número de géneros: evangelios, cartas, hechos, apocalipsis y testamentos, que siempre tienen como referencia los géneros bíblicos. Por todo ello, se trata de un corpus literario muy vasto y nada homogéneo.

considerado entre los recibidos el Evangelio según los hebreos que también podría estar entre los discutidos. El historiador consideró oportuno hacer esta lista para distinguir "los escritos que según la tradición eclesiástica son verdaderos, no inventados, admitidos; y aquellos que difieren: por no ser testamentarios, sino discutidos, los cuales, sin embargo, son conocidos por la mayoría de aquellos que pertenecen a la iglesia. Así podremos conocer estos escritos y los otros, presentados por los heréticos bajo el nombre de los apóstoles, los cuales contienen evangelios considerados ser de Pedro, de Tomás, de Matías o de otros; o Hechos considerados de Andrés, de Juan o de otros apóstoles. Ninguna persona entre la gente de la iglesia regida por las sucesiones (legítimas) ha juzgado digno referir de ningún modo el recuerdo de estos libros en sus escritos. Por lo demás, el carácter de la expresión está alejado fuertemente del estilo apostólico; y el pensamiento y la intención de lo que ahí se encuentra están en completo desacuerdo con la ortodoxia verídica: numerosas pruebas manifiestas de que se trata de fabricaciones de heréticos falsarios. Por eso no hay que colocarlos ni siquiera entre los escritos inauténticos, sino que se les debe proscribir como absurdos e impíos en absoluto" (Argimiro VELASCO DELGADO, Eusebio de Cesarea, Historia Eclesiástica, texto, versión española, introducción y notas, Madrid, BAC 22002, 164-166). Los que califica de absurdos y presentados por los heréticos, hoy son considerados apócrifos.

6 Clemente de Alejandría lo emplea en Stromateis I,69,6 para designar los libros secretos

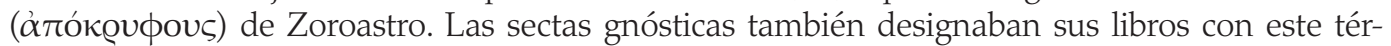
mino para indicar los escritos secretos de diferentes autores como los de Juan, Judas o Tomás (Cf. Christoph MarKSCHIES, Antike christliche Apokryphen in deutscher Übersetzung I, Evangelien und Verwandtes, Tübingen, Mohr Siebeck, 2012, 19, n. 64). Ireneo de Lyon lo empleó con sentido negativo al aludir a los libros secretos y falsos de la secta de los marcosianos en Adversus Haereses I,20,1 y, finalmente, Tertuliano emplea el término latino apocrypha en Pudicitia 10,12, aunque en este caso el sentido original secreto está estrechamente relacionado con"libro que no pertenece al instrumentum divinum".

7 Los tres estudios básicos sobre la definición del término apócrifo son: Jean Daniel KaEsTLi y Daniel Marguerat, Frédéric AmsLer, Rémi Gounelle, Le mystère apocryphe. Introduction à une litterature méconnue, Ginebra, Labor et Fides, 1995; Simon Claude Mimouni (ed.), Apocryphité. Histoire d'un concept transversal aux religions du livre, Turnhout, Brepols, 2002 y Enrico NorelLi, Marie des apocryphes. Enquête sur la mère de Jésus dans le christianisme antique, Ginebra, Labor et Fides, 2006. 


\section{EL CORÁN EN EL CONTEXTO LITERARIO DE LA ANTIGÜEDAD TARDÍA}

Durante los dos últimos siglos, la crítica literaria ha tratado de demostrar que la formación del Corán no respondió únicamente a la actividad literaria islámica, sino que su formación también estuvo determinada por el contexto literario de la Antigüedad tardía. Esta es la razón por la que el texto coránico contiene referencias al texto bíblico y a la literatura que este generó, como la literatura apócrifa cristiana.

Hasta el momento actual, la investigación sobre el texto coránico ha tenido cuatro fases importantes: el nacimiento de esta investigación, el surgimiento de la corriente revisionista, el auge de esta corriente y el estado actual de la cuestión.

La investigación sobre textos religiosos iniciada en el siglo XIX, que supuso la aplicación del método histórico-crítico al texto bíblico, tuvo también su repercusión en lo referente al texto coránico. Fue el momento en el que surgieron las tesis revisionistas sobre los orígenes del islam y se pusieron en duda las tesis de J. E. Renan, Th. Nöldeke y W. M. Watt, cuyos planteamientos pueden sintetizarse en que los orígenes del islam estaban completamente claros y que sus fuentes (El Corán, los hadices y la sunna o tradición) ofrecen conocimientos históricos a través de los que se puede reconstruir de un modo fiable los orígenes del islam y la vida de Muhammad. ${ }^{8}$ Th. Nöldeke, además, en su estudio del Corán, que dividió estilísticamente las azoras en varios periodos, consideró que este no podía someterse al método histórico-crítico y aplicarle la metodología de la duda. ${ }^{9}$

A principios del siglo xx nació la corriente contraria, la revisionista, encabezada por A. Mingana, ${ }^{10}$ A. Jeffery ${ }^{11}$ e I. Goldziher ${ }^{12}$ a los que siguió R. Blachère. ${ }^{13}$ Esta corriente cuestionó tres ideas admitidas por los investigadores del xIX: la inexistencia en el Corán de elementos históricos que ayuden a reconstruir su historia; la historicidad de la cronología de la vida de Muhammad que ofrecen las fuentes islámicas; y el origen árabe, concretamente de Arabia del sur, del Corán. Para esto último, recurrió a la filología con la intención de defender que el lenguaje coránico apuntaba a un entorno siro-palestino más que árabe, lo que situaba al Corán en un contexto norarábigo y no sudarábigo, tal y como defendía la ortodoxia musulmana.

8 Es lo que pretendía William Montgomery WatT con su obra: Muhammad: Prophet and Statesman, Calcuta, Oxford University Press, 1961.

9 Theodor NÖldeKE, Friedrich Zacharias SchwAlly, Gotthelf Bergsträsser y Otto Pretzl, Geschichte des Qôrans, 2 vols. ${ }^{3} 1938$, Leipzig, Dieterich; reimpr. Hildesheim 1961.

10 Cf., Alphonse MinganA, "Syriac Influence on the Style of the Koran”, Bulletin of the John Rylands Library 11 (1927) 77-98, donde el autor apuntó la influencia de la lengua siriaca en el lenguaje del Corán.

11 JEFFERY, The Foreign Vocabulary, donde analiza el léxico coránico de origen hebreo, arameo, griego y siriaco.

12 Ignaz GoldzIHER, Muhammedanische Studien. 2 vols, Halle, Max Nieymeyer, 1889-1890.

13 Regis Blachère, Le Coran, Traduction selon un essai de reclassement des sourates, 3 vols., Paris, G.P. Maisonneuve 1949-1977. 
Esta corriente surgida a principios del siglo xx, no se desarrolló hasta la década de los setenta, cuando la corriente revisionista experimentó un gran auge. Investigadores como G. Lüling, G. R. Puin ${ }^{14}$ y Ch. Luxenberg, en Alemania, y J. E. Wansbrough, M. Cook ${ }^{15}$, R. G. Hoyland y P. Crone ${ }^{16}$, en Inglaterra, situaron al Corán en el contexto literario-religioso de la Antigüedad tardía y plantearon sus relaciones tanto con el judaísmo como con el cristianismo. En cuanto a la literatura, G. Lüling ${ }^{17}$ lo consideró un himnario cristiano fruto de la actividad de una comunidad monoteísta trinitaria y Ch. Luxenberg ${ }^{18}$ descifró a través del siriaco sus pasajes oscuros con un método muy discutido. Con respecto a la historia, R. G. Hoyland ${ }^{19}$ fue el primero en recopilar los textos de las fuentes orientales no islámicas para reconstruir la historia del Corán, y J. E. Wansbrough ${ }^{20}$ inauguró la teoría de que tanto la biografía del Profeta como el lenguaje coránico son una construcción hecha por los seguidores de Muhammad dos siglos después de su nacimiento, quienes trataron de ofrecer de él una historia de Salvación similar a la de otros profetas anteriores.

Finalmente, durante el siglo xxI, la línea revisionista se ha revitalizado y ha tomado dos vías. La primera consiste en el análisis lingüístico y estilístico del texto coránico. La filología estudia el origen árabe y no árabe de la lengua coránica mientras que la literatura comparada se centra en estudiar las narrativas no islámicas del periodo tardo-antiguo, principalmente la literatura rabínica y los apócrifos, para desentrañar su relación con el contenido del Corán. En este campo de investigación se sitúa también su relación con la literatura apócrifa cristiana. Esta última habría funcionado como un subtexto coránico, es decir, como una referencia textual que se contextualizó en un nuevo entorno, el coránico, y a la que se dio un nuevo sentido, el islámico, como se verá más adelante. La segunda vía estudia el contexto religioso de la época en la que nació el islam: el cristianismo nestoriano y jacobita, el judaísmo sinagogal, el maniqueísmo, el judeocristianismo y las tradiciones religiosas autóctonas, para determinar qué hay de original en el Corán y qué procede de otras tradiciones religiosas.

14 Gerd-Rüdiger PuIN, «Über die Bedeutung der ältesten Koranfragmente aus Sanaa (Jemen) für die Orthographiegeschichte des Korans", en Hans-Caspar Graf von Bothmer; Karl-Heinz Ohlig, Neue Wege der Koranforschung; Universität des Saarlandes Magazin Forschung 1 (1999) 37-40.

15 Michael Соок, Muhammad, Oxford 1983; ID., Early Muslim Dogma. A source-critical study, Cambridge-Londres-Nueva York-New Rochelle-Melbourne-Sidney 1981.

16 Patricia Crone y Michael CoOK, Hagarism, the Making of the Islamic World, Cambridge, Cambridge University Press, 1977.

17 Günter LüLING, Über den Ur-Qur'ān: Ansätze zur Rekonstruktion vorislamischer, christlicher Strophenlieder Qur'ān, Erlangen, Lüling, 1974.

18 Christoph. LuXENBERG, Die syro-aramäische Lesart des Koran. Ein Beitrag zur Entschlüsselung der Koransprache, Berlin 2007.

19 Robert G. Hortand, Seeing Islam as others saw it. A Survey and Evaluation of Christian, Jewish and Zoroastrian Writings on Early Islam, Princeton, The Darwin Press, 1997; especialmente el cap. 14: "Using Non-Muslim Sources: An Argumentative Approach", 591-598.

20 John WANSBROUGH, The sectarian milieu: content and composition of Islamic salvation history, London Oriental Series 34, Oxford, Oxford University Press, 1978. 


\section{LITERATURA APÓCRIFA CRISTIANA EN LAS SURAS 3 Y 19}

Los investigadores modernos admiten la presencia de textos apócrifos cristianos en el texto coránico que funcionaron como subtextos en el proceso formativo del Corán. ${ }^{21}$ Una idea bastante aproximada de la cantidad de textos apócrifos presentes en el Corán, es la que ofrece la página web del Corpus Coranicum ${ }^{22}$, un proyecto de la Academia de las Ciencias de Berlín y Brandemburgo, donde en la pestaña dedicada al contexto literario aparece literatura apócrifa judía y cristiana, en total, dieciséis textos; ocho judíos (El apocalipsis de Moisés, El libro de Henoc, El libro de los Jubileos, La vida de Adán y Eva, El Apocalipsis de Baruc, El libro de Esdras, la Sabiduría de Salomón y El testamento de los doce patriarcas); y ocho cristianos (El apocalipsis de Abrahán, El apocalipsis de Juan, El protoevangelio de Santiago, La ascensión de Isaias, El evangelio de la infancia según Tomás, La visión de Pablo, Los salmos de Salomón y La historia de María, la Madre de Dios, a los que pueden añadirse cuatro más: El evangelio árabe de la infancia, El libro etiópico del reposo, El evangelio del pseudo-Mateo y La cueva de los tesoros). Las suras 3 y 19, que relatan varios pasajes de la vida de María y Jesús, son dos de las que contienen más ecos apócrifos.

Los evangelios de Mateo (1,18-25; 2,1-23) y Lucas (1,26-38; 2,1-52) recogen las escuetas noticias que se conservaron en la memoria de la primitiva comunidad cristiana sobre la Anunciación del nacimiento de Jesús, su nacimiento y su infancia. El contenido común de estos dos relatos da a conocer el nombre de su madre, "María", el de su padre adoptivo, "José", el lugar de su nacimiento, "Belén", la huida desde esta ciudad a Egipto después del nacimiento, y el lugar

21 Julio CoRTés, El Corán, Barcelona, Herder ${ }^{3}$ 2005. Evitamos ofrecer el texto árabe original del Corán porque puede consultarse en cualquier edición impresa del Corán. El texto árabe del Corán presenta una gran uniformidad independientemente de la edición que se maneje. Por otra parte, tampoco contamos todavía con una auténtica edición crítica, que muestre las variantes entre las siete lecturas autoritativas del Corán a partir de los manuscritos antiguos de que disponemos hasta ahora. La edición crítica del texto realizada por Gustav Flügel en 1834 (Corani textus arabicus : ad fidem librorum manu scriptorum et impressorum et ad praecipuorum interpretum lectiones et auctoritatem recensuit indicesque triginta sectionum et suratarum, Leipzig 1834, reimpr. 1858) basó su texto únicamente en una lectura, la norteafricana, por lo que actualmente apenas es tenida en cuenta por los investigadores. A su vez, la posterior ordenación de la suras coránicas realizada por Theodor NöLDEKE (v. supra, n. 8), no puede considerarse una edición crítica del texto árabe, ya que su trabajo no consistió en eso. La investigación sobre el Corán se realiza actualmente a partir del texto árabe de la edición de 1924, imprimida en El Cairo y realizada con criterio pedagógico, por ser la versión aceptada como canónica por la comunidad musulmana y la que contienen la mayoría de las ediciones árabes impresas del Corán. Esta es la versión que hemos empleado. Sin embargo, hay que puntualizar, que investigar con esta edición presenta cierta incoherencia metodológica, porque realmente no es una edición crítica del texto y no cuenta con las posibles variantes de los manuscritos cronológicamente más cercanos al período de formación del texto coránico (Pierre LARCHER, "Le Coran: l'écrit, le lu, le récité", en: Mehdi AzaIEz (dir.), Le Coran. Nouvelles Approches, CNRS Editions, Paris 2013, 243-255). Esta edición, hecha con fines catequéticos y no académicos, se realizó unificando el texto también a partir de una sola de sus siete lecturas autoritativas, la de Hafṣ (m. 796) recibida de 'Āṣim (m. 745). Todo ello hace que no dispongamos todavía de una auténtica edición crítica del Corán. $<$ https://corpuscoranicum.de/>. 
donde Jesús pasó su infancia, “Nazaret”. Cronológicamente, parece que estas tradiciones orales, que empezaron a ponerse por escrito a finales del siglo I, fueron aceptadas muy pronto como verdaderas entre la comunidad cristiana primitiva. ${ }^{23}$

El Corán también narra la Anunciación del nacimiento de Jesús y el propio nacimiento. El relato más antiguo de este suceso es el de la sura 19,16-33, revelada en La Meca. Aparece prologado por la anunciación y el nacimiento de Juan el Bautista:

“16.Y recuerda a María en la Escritura, cuando dejó a su familia para retirarse a un lugar de Oriente.17.Y tendió un velo para ocultarse de ellos. Le enviamos Nuestro Espíritu y éste se le presentó como un mortal acabado.18. Dijo ella: «Me refugio de ti en el Compasivo. Si es que temes a Dios...»19. Dijo él: «Yo soy solo el enviado de tu Señor para regalarte un muchacho puro».20. Dijo ella: «¿Cómo puedo tener un muchacho si no me ha tocado mortal, ni soy una ramera?»21. «Así será», dijo. «Tu Señor dice: 'Es cosa fácil para Mí. Para hacer de él signo para la gente y muestra de Nuestra misericordia'. Es cosa decidida».22. Quedó embarazada con él y se retiró con él a un lugar alejado.23. Entonces los dolores de parto la empujaron hacia el tronco de la palmera. Dijo: «¡Ojalá hubiera muerto antes y se me hubiera olvidado del todo...!»24. Entonces, de sus pies, le llamó: «¡No estés triste! Tu Señor ha puesto a tus pies un arroyuelo.25. ¡Sacude hacia ti el tronco de la palmera y esta hará caer sobre ti dátiles frescos, maduros!26. ¡Come, pues, bebe y alégrate!Y, si ves a algún mortal, di: 'He hecho voto de silencio al Compasivo. No voy a hablar, pues, hoy con nadie 27.Y vino con él a los suyos, llevándolo. Dijeron: «¡María! ¡Has hecho algo inaudito!28. ¡Hermana de Aarón! Tu padre no era un hombre malo, ni tu madre una ramera».29. Entonces ella se lo indicó. Dijeron: «¿Cómo vamos a hablar a uno que aún está en la cuna, a un niño?»30. Dijo él: «Soy el siervo de Dios. Él me ha dado la Escritura y ha hecho de mí un profeta.31. Me ha bendecido donde quiera que me encuentre y me ha ordenado la azalá y el azaque mientras viva, 32.y que sea piadoso con mi madre. No me ha hecho violento, desgraciado.33. La paz sobre mí el día que nací, el día que muera y el día que sea resucitado a la vida»."24

Si el relato coránico se compara con los relatos de Lucas y Mateo, es evidente que se hace eco de ellos, que los conoce; pero, al mismo tiempo, se percibe que el relato coránico es diferente porque no menciona a José, en lugar de un ángel presenta al Espíritu como mortal acabado, María se retira a un lugar alejado, tiene dolores de parto, da a luz en un lugar anónimo bajo el tronco de una palmera, suceden dos hechos milagrosos (la palmera inclina sus ramas y surge un arroyo), María vuelve junto a los suyos, que la acusan de ramera y, como ella había hecho voto de silencio, Jesús da las explicaciones pertinentes hablando desde la cuna. La comparación del contenido de los relatos evangélicos y del Corán queda como sigue:

23 En la obra de Ireneo de Lyon aparece por primera vez una conciencia canónica aplicada a los escritos evangélicos. Los limita al número de cuatro (cf. Adversus Haereses III, 11, 8) y especifica la atribución de su autoría: Mateo, Lucas, Marcos y Juan (cf. Adversus Haereses III, 1, 1). Considera que esta colección es normativa para diversas comunidades, es decir, canónica (cerrada) y universal (vinculante) frente a las colecciones que circulaban entre otros cristianos como los valentianianos.

24 Cortés, El Corán. 


\begin{tabular}{|c|c|c|c|}
\hline & 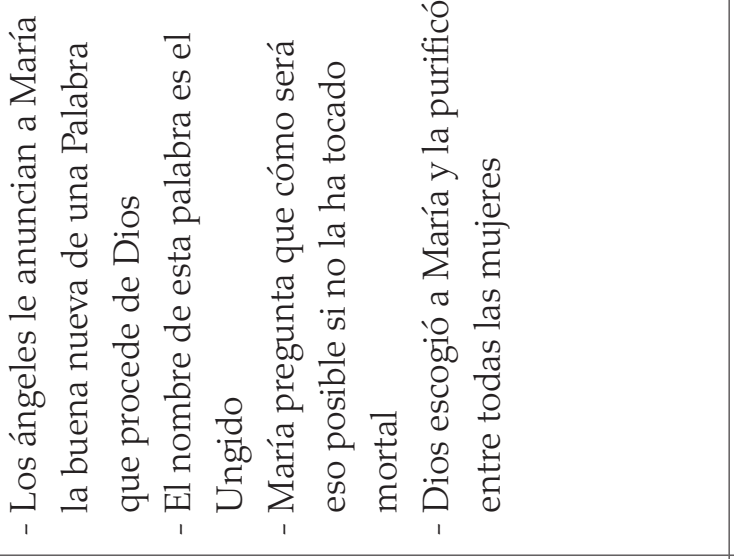 & & 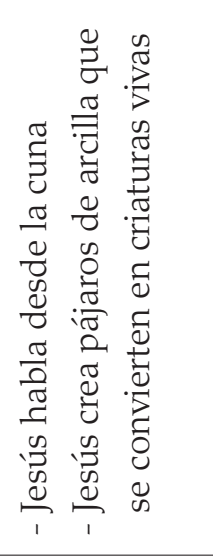 \\
\hline & 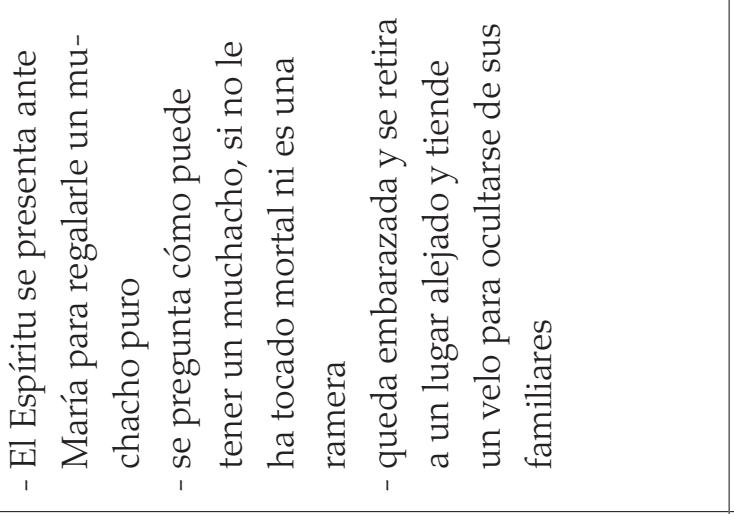 & 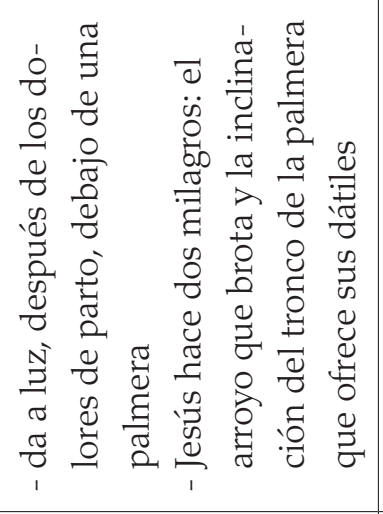 & 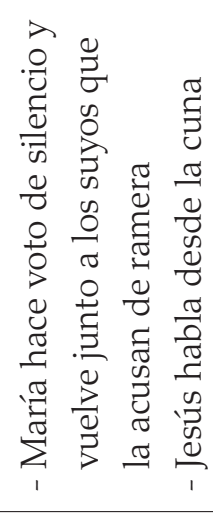 \\
\hline & 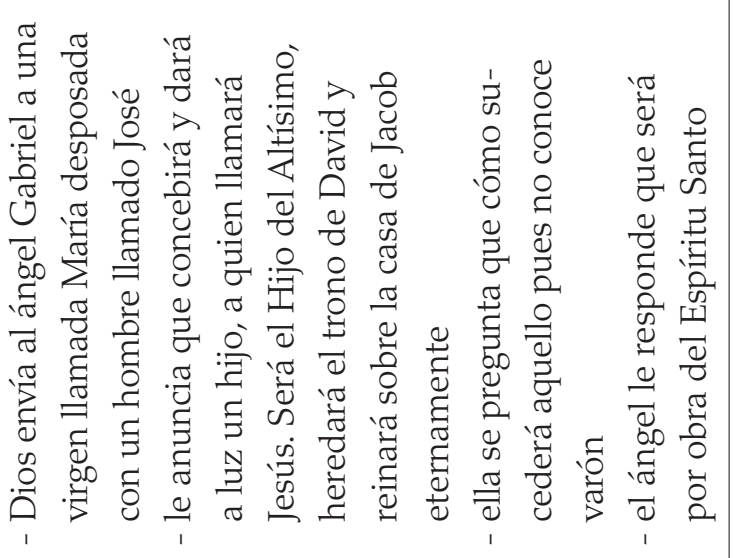 & 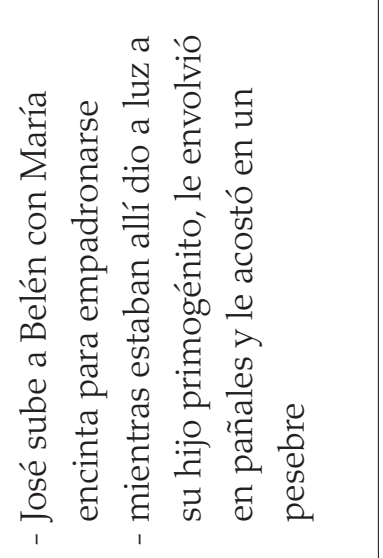 & 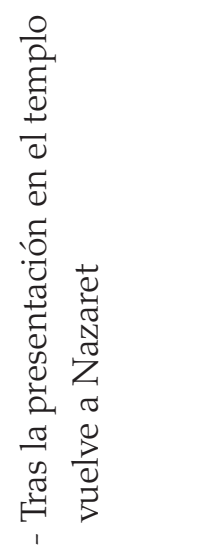 \\
\hline & 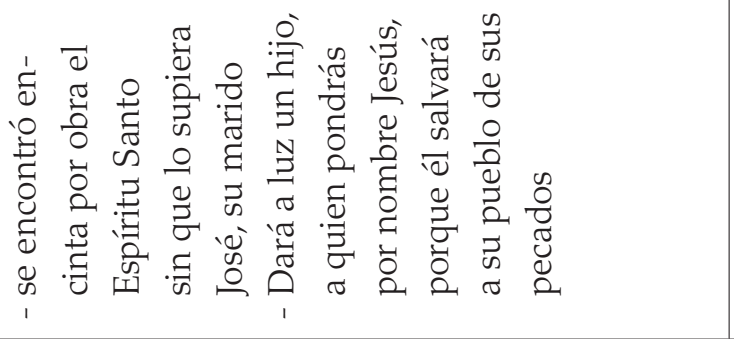 & 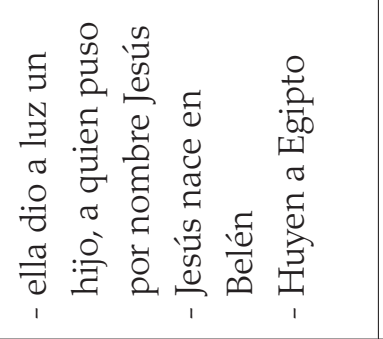 & 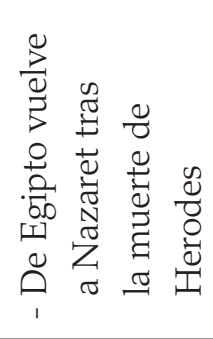 \\
\hline & & 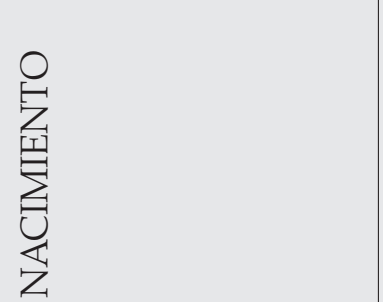 & 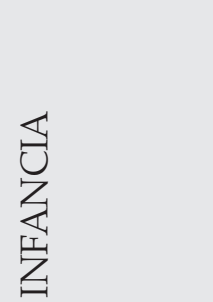 \\
\hline
\end{tabular}


Los sucesos del relato coránico, si bien son ajenos a las noticias que ofrecen los evangelios canónicos, que solo coinciden con ellos en el nombre de María y Jesús, en la concepción sin intervención de varón y en la condición de Jesús de ser diferente al resto de los hombres, no eran extraños ni para los primeros cristianos ni para los cristianos contemporáneos del Corán. En ambientes cristianos circulaban dos relatos que narraban sucesos muy parecidos, El libro etiópico del reposo y El evangelio del pseudo-Mateo.

El primero, ${ }^{25}$ es un relato que nació a finales del s. v o principios del vI, es, por tanto, poco anterior o prácticamente contemporáneo a la revelación del Corán, y recoge en sus secciones más tempranas algunas de las tradiciones sobre María que circularon entre los cristianos siriacos. Cuenta la visión sobre Jesús que María tiene ante la proximidad de la muerte. En ella Jesús se le aparece como Señor de la Creación y le recuerda cómo él habló milagrosamente cuando tenía cinco meses para ordenarle a una palmera que inclinara su copa para que ella pudiera saciar su hambre durante la huida a Egipto:

“El Niño se volvió y le dijo a la palmera: «Inclina tu copa con tus frutos y satisface a mi madre y a mi padre». E inmediatamente se inclinó. ¿Quién la hizo inclinarse? ¿No fue porque tengo poder, que sucedió por mi causa? Tú y José quedasteis satisfechos porque las ramas de la palmera se situaron como la ola del océano en la orilla y la alegría y la felicidad aparecieron en mi cuerpo" 26

Ni el que Jesús hablara con cinco meses, ni el que tuviera poder para hacer que una palmera se inclinase eran algo extraño para los cristianos del siglo vi. Por otro lado, el segundo texto, El evangelio del pseudo-Mateo, que nació en el siglo vi y que en Occidente se conserva en lengua latina, añade al episodio de la palmera el del arroyo:

XX.2. Entonces el niño Jesús, que plácidamente reposaba en el regazo de su madre, dijo a la palmera: «Agáchate, árbol, y con tus frutos da algún refrigerio a mi madre». Y a estas palabras inclinó la palmera su penacho hasta las plantas de María, pudiendo así recoger todo el fruto que necesitaban para saciarse. [...] «Y ahora haz que rompa de tus raíces esa vena de agua escondida de la tierra, para que del manantial podamos saciarnos». Al instante se irguió la palmera y

25 Stephen J. SHOEMAKER, Ancient traditions of the Virgin Mary's Dormition and Assumption, Oxford Nueva York, Oxford University Press, 2002, 34, 153, 158). El texto etiópico de dos manuscritos del s. XV fue editado por Victor ARRAS, De Transitu Mariae apocrypha aethiopice, CSCO 342, Lovaina, Imprimerie Orientaliste, 1973, 1-84, junto con una traducción al latín (ID., De Transitu Mariae apocrypha aethiopice, CSCO 343 Lovaina, Imprimerie Orientaliste 1973, 1-54).

26 V. ARRAS, De Transitu Mariae apocrypha aethiopice, CSCO 343, 3 (7.[...]Et vertit se puer et dixit illi palmae: Inclina caput tuum cum fructu tuo et satia matrem meam patremque meum. Et tunc inclinavit. Et quis inclinavit eam? Nonne quia mihi est potestas quae fuit propter me; et satiata es, tu et Ioseph. Nam rami huius palmae positi ut unda maris super terram; quia ego gaudium et exsultatio in corpore meo apparet). 
empezaron a brotar de entre sus raíces raudales de agua cristalina, fresca y dulcísima en extremo. ${ }^{27}$

La diferencia clave con el Corán es que este episodio sucede durante la huida a Egipto y no en el momento del nacimiento de Jesús. Parece que la tradición de que el nacimiento de Jesús tuvo lugar en Belén estaba consolidada en los ambientes cristianos mientras que el Corán, menos preciso, no lo localiza en ninguna ciudad concreta. María se encuentra en un lugar alejado de su familia y hacia él se dirige cuando le llega el momento del parto. Ante este argumento, se puede concluir que lo que le interesa al Corán es destacar el malestar y los dolores de parto que sufre María más que indicar con precisión el lugar exacto donde nació Jesús.

Hay otro suceso que tampoco recogen los evangelios canónicos, pero en el que los relatos apócrifos de nuevo coinciden con el Corán: el hecho de que Jesús hable desde la cuna a su madre y a los que están con ella. En la sura 19 leemos cómo María, que ha hecho voto de silencio, señala al niño para defenderse de los que la acusan de ramera y este habla milagrosamente:

“28. «iHermana de Aarón! Tu padre no era un hombre malo, ni tu madre una ramera».29. Entonces ella se lo indicó. Dijeron: «¿Cómo vamos a hablar a uno que aún está en la cuna, a un niño?» 30. Dijo él: «Soy el siervo de Dios. Él me ha dado la Escritura y ha hecho de mí un profeta.31. Me ha bendecido dondequiera que me encuentre y me ha ordenado la azalá y el azaque mientras viva, 32. y que sea piadoso con mi madre. No me ha hecho violento, desgraciado.33. La paz sobre mí el día que nací, el día que muera y el día que sea resucitado a la vida»."28

El evangelio árabe de la infancia cuyo arquetipo siriaco debía circular en el siglo v entre los cristianos de Oriente, presenta también a Jesús hablando desde la cuna:

"I.I. Encontramos lo que sigue en el libro del pontífice Josefo, sacerdote que vivió en los tiempos de Cristo y a quien algunos identifican con Caifás. I.2.Dijo esto: «Jesús habló cuando se encontraba precisamente reclinado en la cuna», y que

27 Aurelio de Santos Otero, Los Evangelios apócrifos. Edición crítica y bilingüe, BAC 148, Madrid 1956, 13 reimpr. 2006, 213 (Tunc infantulus lesus laeto vultu in sinu matris residens ait ad palmam:'Flectere, arbor, et de fructibus tuis refice matrem meam'. Et confestim ad han vocem inclinavit palma cacumen suum usque ad plantas Mariae, et collegerunt ex ea fructus quibus omnes refecti sum. [...]Aperi autem ex radicibus tuis venam quae absconsa est in terra, et fluant ex ea aquae ad satietatem nostram'. Et statim erecta est palma, et coeperunt per radices eius egredi fontes aquarum limpidissimi et frigidi et dulcissimi nimis). Este evangelio latino debió nacer en Occidente a mediados del s. vI, pero reelabora elementos procedentes de El protoevangelio y El evangelio del pseudo-Tomás, ambos textos conocidos en Oriente como muestran sus versiones siriacas. El último se fecha a finales del s. II (cf. SANTOS OtERO, Los Evangelios apócrifos, 171, 277-278).

28 Julio CoRTés, El Corán. 
dijo a su madre: «Yo soy Jesús, el hijo de Dios, el Verbo, quien tú has dado a luz de acuerdo con el anuncio del ángel Gabriel. Mi Padre me ha enviado para la salvación del mundo»." ${ }^{29}$

La sura 3 revelada en Medina y, por tanto, posterior a la que acabamos de analizar, también se refiere a la infancia de María y de Jesús (3,33-44; y3,45-59). Los versículos 45-59 relatan la anunciación, el nacimiento de Jesús y su vida pública:

“45. Cuando los ángeles dijeron: «¡María! Dios te anuncia la buena nueva de una Palabra que procede de Él. Su nombre es el Ungido, Jesús, hijo de María, considerado en la vida de acá y en la otra y será de los allegados. 46. Hablará a la gente en la cuna y de adulto, y será de los justos». 47. Dijo ella: «jeñor! ¿Cómo puedo tener un hijo, si no me ha tocado mortal?» Dijo: «Así será. Dios crea lo que Él quiere. Cuando decide algo, le dice tan sólo: ‘Sé!' y es. 48. Él le enseñará la Escritura, la Sabiduría, la Torá y el Evangelio». 49. Y como enviado a los Hijos de Israel: «Os he traído un signo que viene de vuestro Señor. Voy a crear para vosotros, de la arcilla, a modo de pájaros. Entonces, soplaré en ellos y, con permiso de Dios, se convertirán en pájaros. Con permiso de Dios, curaré al ciego de nacimiento y al leproso y resucitaré a los muertos. Os informaré de lo que coméis y de lo que almacenáis en vuestras casas. Ciertamente, tenéis en ello un signo, si es que sois creyentes. 50. Y en confirmación de la Torá anterior a mí y para declararos lícitas algunas de las cosas que se os han prohibido. Y os he traído un signo que viene de vuestro Señor. ¡Temed, pues, a Dios y obedecedme! 51. Dios es mi Señor y Señor vuestro. ¡Servidle, pues! Esto es una vía recta». 52. Pero, cuando Jesús percibió su incredulidad, dijo: «¿Quiénes son mis auxiliares en la vía que lleva a Dios?» Los apóstoles dijeron: «Nosotros somos los auxiliares de Dios. ¡Creemos en Dios! ¡Sé testigo de nuestra sumisión! 53. Señor! Creemos en lo que has revelado y seguimos al enviado. Inscríbenos, pues, entre los que dan testimonio». 54. E intrigaron y Dios intrigó también. Pero Dios es el Mejor de los que intrigan. 55. Cuando Dios dijo: «jJesús! Voy a llamarte a Mí, voy a elevarte a Mí, voy a librarte de los que no creen y poner, hasta el día de la Resurrección, a los que te siguen por encima de los que no creen. Luego, volveréis a Mí y decidiré entre vosotros sobre aquello en que discrepabais. 56. A quienes no crean les castigaré severamente en la vida de acá y en la otra.Y no tendrán quienes les auxilien. 57. En cuanto a quienes crean y obren bien, Él les remunerará debidamente. Dios no ama a los impíos». 58. Esto te recitamos de las aleyas y de la sabia Amonestación. 59. Para Dios, Jesús es semejante a Adán, a quien creó de tierra y a quien dijo: «iSé!»y fue. ${ }^{30}$

29 Santos Otero, Los Evangelios apócrifos, 303-304 (traducción castellana del texto latino de C. Tischendorf, Evangelia Apocrypha, Leipzig 1853, Hildesheim 1987, 181-209. Texto árabe, J. C. Thilo, Codex Apocryphus Novi Testamenti, tomus primus, Lipsiae MDCCCXXXII, 66:

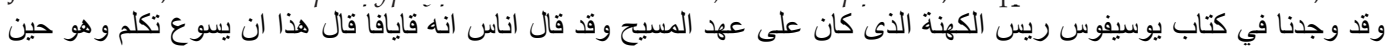

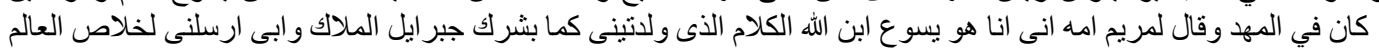


De nuevo el Corán se hace eco de la concepción milagrosa de Jesús en lo que coincide con Mateo y Lucas, retoma el episodio de las palabras pronunciadas desde la cuna del Evangelio árabe de la infancia, pero añade un nuevo milagro: la creación de unos pájaros de arcilla en los que soplará y que, con el permiso de Dios, se convertirán en pájaros. Este mismo evangelio también relata un suceso parecido, la creación por parte de Jesús de unos animales de barro, entre los que también había pájaros, que cobraron vida llegando a volar, comer y beber:

“2. Cumplió el niño Jesús los siete años y estaba un día entretenido jugando con los muchachos de su misma edad. Todos se divertían haciendo con barro figurillas de asnos, bueyes, pájaros y otros animales. Cada cual hacía alarde de sus habilidades y aplaudía su trabajo. Entonces dijo Jesús a los demás: «Yo voy a mandar correr a mis figurillas». Admirados los otros le preguntaron si por ventura era hijo del Creador. 2. Entonces Jesús las mandó ponerse en movimiento, y ellas empezaron a saltar. Luego, a una indicación suya, se volvieron a parar. Había hecho también figuras de pájaros y aves, que, al oír su voz, se echaban a volar; mas cuando las mandaba estarse quietas, se paraban. Y siempre que les ponía algo de comer o de beber, ellas comían y bebían". ${ }^{31}$

La narración coránica de la sura 3 está precedida de los versículos 33-44 que introducen una novedad aún mayor con respecto a los evangelios canónicos, ya que, antes de informar sobre el nacimiento y la infancia de Jesús, informan sobre el nacimiento y la infancia de su madre:

“33. Dios ha escogido a Adán, a Noé, a la familia de Abraham y a la de Imrán por encima de todos, 34. como descendientes unos de otros. Dios todo lo oye, todo lo sabe. 35. Cuando la mujer de Imrán dijo: «iSeñor! Te ofrezco en voto, a Tu exclusivo servicio, lo que hay en mi seno. ¡Acéptamelo! Tú eres Quien todo lo oye, Quien todo lo sabe». 36. Y cuando dio a luz a una hija, dijo: « Señor! Lo que he dado a luz es una hembra - bien sabía Dios lo que había dado a luz- y un varón no es igual que una hembra. Le he puesto por nombre María y la pongo bajo Tu protección contra el maldito Demonio, y también a su descendencia». 37. Su Señor la acogió favorablemente, la hizo crecer bien y la confió a Zacarías. Siempre que Zacarías entraba en el Templo para verla, encontraba sustento junto a ella. Decía: «iMaría!, ¿de dónde te viene eso?» Decía ella: «De Dios. Dios provee sin medida a quien Él quiere». 38. Entonces, Zacarías invocó a su Señor diciendo: «iSeñor! ¡Regálame, de Ti, una descendencia buena! Tú escuchas a quien Te invoca». 39.

31 Santos Otero, Los Evangelios apócrifos, 324. Texto árabe J. C. Thilo, Codex Apocryphus ولما كمل الرب يسوع سبع سنين من ميلاده كان ذات يو مع مع اطفال اتر ابه اعنى الذين هم من اقر انها :

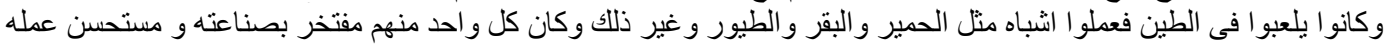

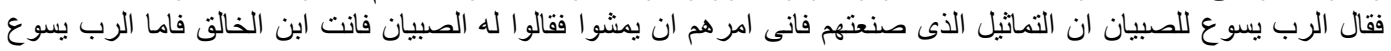

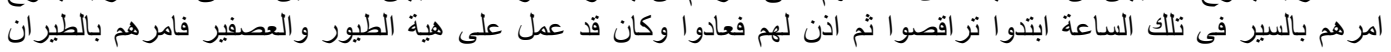

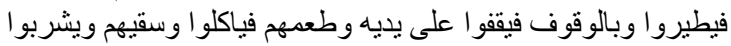


Los ángeles le llamaron cuando, de pie, oraba en el Templo: «Dios te anuncia la buena nueva de Juan, en confirmación de una Palabra que procede de Dios, y que será jefe, abstinente, profeta, de los justos». 40. «jeñor!» dijo, «¿cómo puedo tener un muchacho si soy ya viejo y mi mujer estéril?» Dijo: «Así será. Dios hace lo que Él quiere». 41. Dijo: «jeñor! ¡Dame un signo!» Dijo: «Tu signo será que no podrás hablar a la gente durante tres días sino por señas. Recuerda mucho a tu Señor y glorifícale, al anochecer y al alba». 42. Y cuando los ángeles dijeron: « María! Dios te ha escogido y purificado. Te ha escogido entre todas las mujeres del universo. 43. ¡María! ¡Ten devoción a tu Señor, prostérnate e inclínate con los que se inclinan!» 44. Esto forma parte de las historias referentes a lo oculto, que Nosotros te revelamos. Tú no estabas con ellos cuando echaban suertes con sus cañas para ver quién de ellos iba a encargarse de María. Tú no estabas con ellos cuando disputaban". ${ }^{32}$

Todos estos sucesos novedosos del relato coránico: el voto de ofrecer lo que nazca a Dios que hace la madre de María, su ubicación en el Templo (en 19.16 se decía que se retiró a un lugar alejado y que tendió un velo), el que Zacarías siempre encontrara sustento junto a ella procedente de Dios y el que algunos echaran a suertes con sus cañas quién se hacía cargo de María tampoco eran extraños para los cristianos que escucharan la recitación del Corán. El protoevangelio de Santiago, obra de un cristiano anónimo de Egipto o Siria en el siglo II, que sufrió numerosas reelaboraciones y cuyos episodios fueron muy populares, cuenta in extenso los sucesos a los que alude el Corán. Compuesto originalmente en griego, su versión siriaca que, probablemente fue la que conocieron los cristianos contemporáneos al Corán, explica cómo Ana, la madre de María, pronuncia un voto como acción de gracias por su concepción milagrosa tras los cuarenta días de ayuno de Joaquín y sus súplicas a Dios:

"IV.1. Y mientras Ana decía estas cosas, un ángel del Señor se puso ante ella y le dijo: — «Ana, el Señor ha escuchado tu súplica: concebirás y darás a luz, y se hablará de tu descendencia en toda la tierra».Y Ana dijo: — «Vive el Señor, mi Dios: tanto si la criatura es varón como si es hembra, la ofreceré al Señor Dios, y le servirá todos los días de su vida»". ${ }^{33}$

Después, cuando María cumple seis meses, sus padres deciden preservarla en un lugar aislado hasta que pueda entrar en la casa del Señor:

32 CORTÉs, El Corán.

33 Pilar González Casado, Jacinto González Núñez, Consolación Isart Hernández, El protoevangelio de Santiago, Apócrifos Cristianos 3, Madrid - Buenos Aires 1997, 154 (traducción del texto siriaco de Agnes SmIth LewIS. Apocrypha Syriaca. Studia Sinaitica XI (1902)

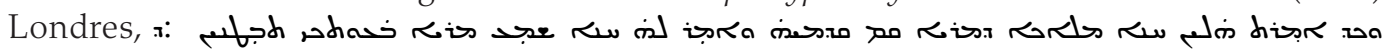

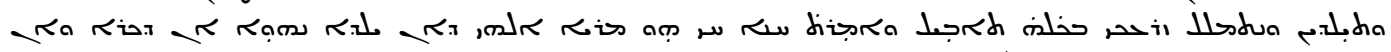

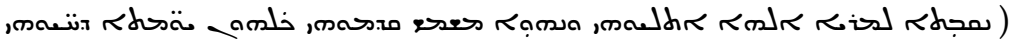


“VI.1.[...] Entonces la aupó y dijo: — «Vive el Señor mi Dios que no caminarás sobre el suelo hasta que te lleve a la casa del Señor». Sus padres le hicieron un santuario en su habitación y no permitían que se acercase allí nada que fuese impuro o que no fuese puro". ${ }^{34}$

Y, una vez que habita en el templo, un ángel le trae comida:

"VIII.1. Sus padres bajaron de allí alabando al Señor porque (la niña) no se había vuelto con ellos. Estaba en el templo del Señor alimentada como una paloma y recibía el alimento de manos de un ángel" ${ }^{35}$

Cuando llega a la pubertad, ha de salir del templo. Los sacerdotes deciden que Zacarías pida un signo a Dios que les indique qué hacer con María. El ángel del Señor se le presenta y le dice que reúna a los viudos del pueblo, que cada uno traiga una vara y el dueño de la vara sobre la que el Señor muestre un signo, será el esposo de María. El sacerdote recoge todas las varas, entra en el templo y ora. Después sale y se las reparte a sus dueños. De la vara de José sale una paloma y se posa sobre su cabeza, lo que se interpreta como signo de que es el elegido para hacerse cargo de María. ${ }^{36}$ A este suceso es al que se refiere el Corán cuando en 19,44 habla de que echaron a suertes con sus cañas para ver quién iba a encargarse de María.

\section{EL PROCESO DE REELABORACIÓN CORÁNICO DE LA LITERATURA APÓCRIFA CRSTIANA}

\subsection{El recurso formal}

Una comparación entre los textos coránicos y los apócrifos cristianos citados más arriba pone de manifiesto que el Corán no relata los sucesos referentes a Jesús y María de un modo literal con respecto a cómo los relatan los apócrifos, sino que, simplemente, los rememora, porque da por supuesto que son conocidos. Esta rememoración se realiza a través de dos vías, una formal y otra conceptual. La primera consiste en un recurso estilístico que actualiza en la memoria del oyente subtextos anteriores o contemporáneos cronológicamente. La segunda consiste en cambiar el contenido del subtexto en su nuevo contexto para darle un nuevo sentido.

34 González Casado, González Núñez, Isart Hernández, El protoevangelio, 157. (Texto siriaco en SMith LewIS, m: ma

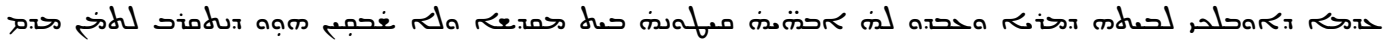

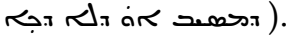

35 González Casado, González Núñez, Isart Hernández, El protoevangelio, 160-161.

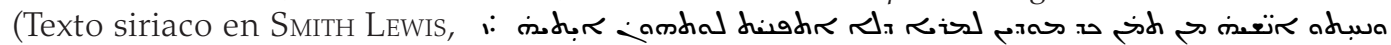

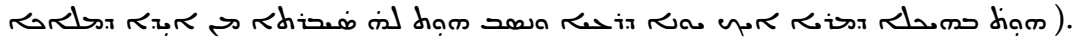

36 Cf. Protoevangelio, VIII.3-IX.1. 
El recurso estilístico es un mecanismo que consiste en ordenar una acción a los destinatarios del mensaje por medio de la utilización de un imperativo. La aleya 16 de la sura 19, llamada María, comienza precisamente, cuando va a relatar la anunciación, con la siguiente expresión: أذكُرْ في الكتاب مريخ ,'Y recuerda a María en la Escritura". El imperativo udkur, "recuerda", indica que lo que se va a narrar no es algo nuevo, sino algo conocido ya por aquellos a los que dirige el mensaje. Los sucesos explicados en el Corán pertenecían al contexto literario de sus oyentes, que tenían una Escritura, un kitāa, que los contenía. Este imperativo es el mecanismo que emplea el texto coránico para re-contextualizar textos precedentes y situarlos en un contexto nuevo. El nuevo contexto es el coránico y con esta re-contextualización pretende ofrecer la versión auténtica de los hechos narrados e invalidar la anterior. Otros pasajes del texto coránico, como 19,41; 19,51 y 19,54, también emplean el imperativo udkur para recordar lo que se dijo en la Escritura sobre Abrahán, Moisés e Ismael y situar a los patriarcas del Antiguo Testamento en el nuevo contexto coránico. ${ }^{37}$

\subsection{El cambio de sentido del contenido}

Una vez que el subtexto ha sido aludido y actualizado con el recurso del imperativo, el Corán ofrece la versión auténtica de él cambiando el contenido del subtexto conocido. Tres pasajes de los textos anteriores ejemplifican este proceso.

\subsubsection{Las palabras desde la cuna}

En ambos pasajes Jesús habla desde la cuna, pero no dice las mismas palabras:

\begin{tabular}{|c|c|}
\hline Corán 19,30-31 & Evangelio árabe de la infancia, I \\
\hline $\begin{array}{r}\text { 30."Soy el siervo de Dios. Él me ha } \\
\text { dado la Escritura y ha hecho de mí un } \\
\text { profeta. 31. Me ha bendecido donde- } \\
\text { quiera que me encuentre y me ha orde- } \\
\text { nado la azalá y el azaque mientras viva" }\end{array}$ & $\begin{array}{l}\text { "Yo soy Jesús, el hijo de Dios, } \\
\text { elVerbo, quien tú has dado a luz de } \\
\text { acuerdo con el anuncio del ángel } \\
\text { Gabriel. Mi Padre me ha enviado } \\
\text { para la salvación del mundo" }\end{array}$ \\
\hline
\end{tabular}

Cada texto hace una afirmación dogmática sobre la persona de Jesús conدبعَ forme a su propia fe. En el Corán Jesús es un siervo de Dios. El término ('abd) siervo es un tecnicismo coránico para definir la relación existente entre el hombre creado por Dios y Dios, según se entiende a partir de la sura 51,56. ${ }^{38} \mathrm{~A}$

37 Cf. Loren D. Lybarger, "Gender and Prophetic Authority in the Qur'anic Story of Maryam: A Literary Approach", Journal of Religion 80 (2000) 240-270.

38 51,56: "No he creado a los genios y a los hombres sino para que me sirvan” (CoRTÉs, El Corán). 
lo largo del Corán, los patriarcas del Antiguo Testamento son presentados como siervos de Dios y Jesús, el Ungido, cuyo estatus se esclarece en 4,171, es definido también como "siervo de Dios" en el versículo siguiente. ${ }^{39}$ Finalmente, el Corán en 3,59 equipara a Jesús con Adán para expresar su condición de hombre creado: "Para Dios, Jesús es semejante a Adán a quien creó de tierra y a quien le dijo: «jSé!» y fue". En El evangelio árabe de la infancia, un texto de carácter monofisita que entiende que en Jesús hay una sola naturaleza, la divina, Jesús afirma su divinidad al ser hijo de Dios. En el Corán, Dios le ha dado una Escritura, pero no es el Verbo, la Palabra de Dios encarnada en un hombre. En el Corán su misión es ser profeta y Dios le ha ordenado la oración y la limosna, claras prescripciones coránicas. En el apócrifo es enviado de su Padre que le ha encomendado una misión: salvar al mundo. De este modo, el Corán transforma al Jesús divino apócrifo en el Jesús humano coránico.

\subsubsection{Los pájaros de arcilla}

Esta caracterización de Jesús continúa a lo largo de estas dos suras en las que hay varias aleyas que suponen el culmen de este proceso. En 19,47 cuando María se pregunta cómo podrá tener un hijo si no la ha tocado varón, el ángel le responde que Dios crea lo que Él quiere. Es un nuevo atributo del Jesús coránico que es creado por Dios, no engendrado por Dios ni Él mismo Creador. Ese Jesús creado traerá un signo $(19,49)$ a los hombres para confirmar que sus milagros no son fruto de su poder como Creador, sino que, como cualquier hombre, los realiza con el permiso de Dios, porque Dios se lo concede. El primer signo de su taumaturgia por permiso divino será el milagro de los pájaros de arcilla que en El evangelio árabe de la infancia tenía justamente el sentido opuesto: Jesús lo realiza para responder afirmativamente sin palabras al amigo que le pregunta si él es hijo del Creador. Sacar vida del barro, a semejanza de Génesis 2,7, implica ser Creador.

\subsubsection{La figura de María}

Si tanto en los evangelios canónicos como en los relatos apócrifos la figura de María está subordinada al significado teológico de la persona de Jesús, en el Corán está vinculada a Jesús, pero resalta un nuevo aspecto de María, su vínculo con la estirpe sacerdotal de Israel.

39 4,171-172: “171. ¡Gente de la Escritura! ¡No exageréis en vuestra religión! ¡No digáis de Dios sino la verdad: que el Ungido, Jesús, hijo de María, es solamente el enviado de Dios y Su Palabra, que Él ha comunicado a María, y un espíritu que procede de Él! ¡Creed, pues, en Dios y en Sus enviados! ¡No digáis «Tres»! ¡Basta ya, será mejor para vosotros! Dios es solo un Dios Uno. ¡Gloria a Él! Tener un hijo... Suyo es lo que está en los cielos y en la tierra... ¡Dios basta como protector! 172. El Ungido no tendrá a menos ser siervo de Dios, ni tampoco los ángeles allegados. A todos aquellos que tengan a menos servirle y hayan sido altivos les congregará hacia Sín (Cortés, El Corán). 
El nexo sacerdotal es expresado por la genealogía de María, el nuevo escenario donde tiene lugar el anuncio del nacimiento de Jesús y la desvinculación del nacimiento de la ciudad de Belén. La sura 3, titulada Los `imrān o La familia de `Imrān, comienza con una breve genealogía:

"Dios ha escogido a Adán, a Noé, a la familia de Abraham y a la de Imran por encima de todos, 34. como descendientes unos de otros. Dios todo lo oye, todo lo sabe. 35. Cuando la mujer de Imran..."

Aparecen cuatro patriarcas: Adán, Noé, Abrahán e 'Imrán. Todos de origen bíblico. Para el propósito del Corán, el cuarto es el más significativo al sustituir a Moisés. Según el Corán 3, 35, 'Imrán es el padre de María, puesto que su mujer, de la que no se dice el nombre, es la madre de María, como se ve de 3,35 a 36. De la sucesión bíblica de patriarcas se elimina a Moisés y se sustituye a Joaquín, padre de María, según El protoevangelio, ${ }^{40}$ por el padre de Aarón. Luego a María, al ser hermana de Aarón, como se dice en 19,28, se la hace descender de la estirpe sacerdotal. ${ }^{41}$ La anunciación del nacimiento de Jesús en el templo y el que no aparezca el nombre de la ciudad donde este nació es un modo de revivificar los recuerdos de la tradición del templo fundada en Aarón. La relación existente entre el templo y María presenta a la familia fundadora del cristianismo como la heredera de la estirpe sacerdotal del templo y la heredera de Abrahán. Así se contrarresta la elección única del pueblo judío que ahora reside también en el pueblo de la nueva fe monoteísta y se crea una contratradición con respecto a la existente.

La dimensión sacerdotal de la figura de María y la cuestión de su linaje eran temas habituales de la literatura cristiana que debió conocer el Corán. Por un lado, la literatura siriaca exegética la relaciona con Aarón como alegoría de su concepción virginal. San Efrén, Padre de la Iglesia siriaca del siglo iv (306-373) y, probablemente, su figura más representativa, equipara a María con la vara de Aarón florecida en los himnos de la Natividad. ${ }^{42}$ Y, por otro, la literatura apócrifa abunda en su genealogía y la presenta como depositaria de la Alianza divina por su relación con el rey David. ${ }^{43}$

40 Cf. El protoevangelio, II.1 y V.2.

41 Éxodo 16,18 presenta a Amrán como descendiente de Leví por la línea de su hijo Quehat y 16,20 da el nombre de sus dos hijo: Aarón y Moisés.

42 "La vara de Aarón floreció y reverdeció el leño seco / Su símbolo hoy se ha explicado,

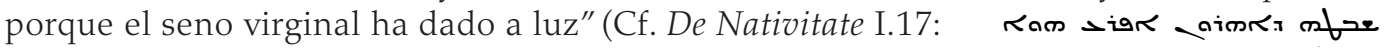

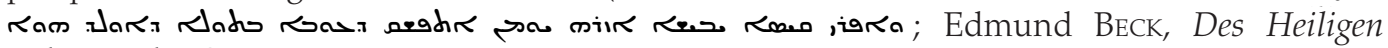
$\bar{E}$ phraem des Syrers Hymnen de Nativitate (Epiphania). 1, Corpus Scriptorum Christianorum Orientalium 186, Scriptores Syri 82, Secrétariat du Corpus SCO, Lovaina 1959, 3).

43 La cueva de los tesoros, relato siriaco sobre la historia de la salvación muy popular entre los cristianos mesopotámicos del siglo vI, dedica varios capítulos a esta cuestión (XLIII:15-25). La elección de los reyes del pueblo de Israel como depositarios de la Alianza divina surge en el momento de la Creación, concretada en la tribu del rey David, tribu de la que descenderá María, madre del Mesías Rey (cf. Pilar GonzÁlez CAsado, La cueva de los tesoros, Apócrifos Cristianos 5, Madrid, Ciudad Nueva, 2005, 30). 
Este fenómeno puede interpretarse como una tendencia coránica a neutralizar la presencia judía y, sobre todo, su autoridad a la hora de heredar la estirpe sacerdotal y de interpretar la Escritura entregada por Dios. En las dos suras analizadas (3 y 19) se aprecia que esta función ya no es exclusiva del pueblo judío, ya que el ángel le anuncia a María que Dios le enseñará a Jesús la Escritura, la sabiduría, la Torá y el Evangelio $(19,48)$; y la sura de āl-'Imrān $(3,7)$ comienza mencionando que hay aleyas unívocas (muhkama) y también equívocas (mutašābiha $)^{44}$, lo que indica que había comenzado un proceso de exégesis del Corán en Medina. En La Meca, según explica el mismo Corán, este era claro, ${ }^{45}$ es decir, este proceso de exégesis no se había iniciado y, por tanto, no era necesario que la comunidad coránica se auto-atribuyera la autoridad de interpretar los textos revelados que ostentaba únicamente la comunidad judía. Con la atribución del linaje sacerdotal a la familia de 'Imrān de la que nace Jesús, esta autoridad exegética pasa del judaísmo al cristianismo y, finalmente, al islam del que el profeta Jesús forma parte. Esto aclarara el motivo por el que la sura 3 es una reelaboración medinesa de la 19 gracias a la nueva contextualización de los sucesos narrados por El protoevangelio de Santiago.

Por último, la figura coránica de María aparece ligada a Jesús, como en los apócrifos, pero es despojada de su significado cristológico. Si Jesús no es hijo de Dios, sino solo hijo de la mujer María, María no es madre de Dios, sino del hombre Jesús. Tanto El protoevangelio (XVIII) como El pseudo-Mateo (XIII.2) describen un parto indoloro de María, mientras que el Corán $(19,22)$ explícitamente habla de los dolores del parto que la empujaron hacia el tronco de la palmera para dar a luz. El protoevangelio recoge una mariología popular primitiva en la que están presentes creencias que se definirán dogmáticamente en el dogma de la Madre de Dios hacia el siglo v en el concilio de Éfeso (431). El apócrifo resalta la elección de María por parte de Dios, que la preserva del pecado original, y su parto milagroso. La consecuencia inmediata de estar preservada de este pecado es parir sin dolor, ya que, en María, que no tiene pecado original, no se cumple lo que afirma el Génesis $(3,16)$ que padecerán las descendientes de la Eva transgresora del mandamiento divino. El Corán, aunque admite la elección y la purificación de María e, incluso, que su madre la ponga bajo la protección de Dios para evitar la acción del maldito demonio en ella $(3,36)$, esta predilección no impide que padezca dolores de parto. Si a esto se le une el hecho de que Dios no es el que engendra a Jesús en el seno de María, sino que lo crea en él, la figura de María se re-contextualiza sin vinculación cristológica.

44 “3. 7. Él es Quien te ha revelado la Escritura. Algunas de sus aleyas son unívocas y constituyen la Escritura Matriz; otras son equívocas. Los de corazón extraviado siguen las equívocas, por espíritu de discordia y por ganas de dar la interpretación de ello. Pero nadie sino Dios conoce la interpretación de ello. Los arraigados en la Ciencia dicen: «Creemos en ello. Todo procede de nuestro Señor». Pero no se dejan amonestar sino los dotados de intelecto" (CoRTÉs, El Corán). 


\section{CONCLUSIÓN}

Los tres ejemplos presentados muestran cuál es la causa del vínculo estrecho que existe entre la Literatura apócrifa cristiana y el Corán: re-contextualizar las tradiciones cristianas precedentes y ponerlas al servicio del nuevo mensaje coránico. En el nuevo contexto la persona de Jesús es definida como hombreprofeta y la naciente comunidad musulmana como la heredera de la interpretación de la Escritura judía y cristiana.

Esta presencia de la literatura apócrifa en el Corán confirma el hecho de que los primeros oyentes del Corán la conocían. Probablemente les llegó a través de la tradición oral, puesto que por ahora no se han descubierto testimonios documentales en árabe de estos textos y, los que han aparecido, son bastante posteriores. En cuanto a las lenguas, debieron conocerla en las lenguas vernáculas y litúrgicas de los cristianos que habitaban tanto la periferia de la Península Arábiga como Mesopotamia y sus alrededores. Los cristianos de la región de Beth Arbaye, situada entre la ciudad de Nísibe y el río Tigris, cuyas tribus habían sido evangelizadas en el siglo VI, se expresaban en siriaco y en árabe. En la zona de Palestina en el siglo v, en las áreas controladas por las tribus árabes de los lajmíes (jacobitas) y los gassaníes (nestorianos), el árabe era la lengua dominante, pero sus contactos con las iglesias jacobita y nestoriana de habla siriaca fueron constantes en una zona en la que el siriaco alternaba con el griego como lengua franca. En siriaco nació El evangelio árabe de la Infancia y El protoevangelio de Santiago, este último núcleo literario de El pseudo-Mateo. Por lo que respecta a El libro etiópico del reposo, parece que en el sur de Arabia hubo una presencia etiópica importante a través de la que pudo difundirse este relato y ser conocido para los que escuchaban el Corán. ${ }^{46}$

Una última cuestión debe ser abordada para apuntar una posible explicación acerca de cómo armonizar la entrada de la literatura apócrifa cristiana en el Corán con su estatus de Escritura divina descendida con un contenido cerrado desde el principio. Una posible explicación puede darla el propio texto coránico, que contiene una acusación vertida contra Muhammad por los que cuestionaban su mensaje porque no era original. ${ }^{47}$ Esta falta de originalidad provendría de haber conocido una serie de tradiciones textuales religiosas anteriores al Corán que serían escritos que el texto coránico tenía ante él, hecho que el Corán no niega, sino que afirma porque lo que dice es que la Escritura coránica ha descendido para confirmar, detallar e interpretar, las Escrituras

46 Acerca de las últimas investigaciones sobre la identidad cristiana de los primeros oyentes del Corán y su pertenencia lingüística, puede consultarles, Sidney H. Grifrith, The Bible in Arabic. The Scriptures of the "People of the Book" in the Language of Islam, Princeton University Press, Princeton 2015, 7-97.

47 “25. 4. Dicen los infieles: «Esto no es sino una mentira, que él se ha inventado y en la que otra gente le ha ayudado» [...] 5.Y dicen: «Patrañas de los antiguos que él se ha apuntado [...]»"(CORTÉs, El Corán). 
anteriores a él, y no para negarlas. ${ }^{48}$ Este proceso de confirmación e interpretación lo realiza mediante el mecanismo descrito anteriormente de la re-contextualización por medio del imperativo أُْْكُرْ (ud kur) "recuerda"49 y prueba que el Corán no es solo un producto de la actividad literaria islámica, sino que su formación estuvo también determinada por el contexto literario-religioso de la Antigüedad tardía.

48 “10.37. Este Corán no puede haberlo inventado nadie fuera de Dios. No solo eso, sino que viene a confirmar los mensajes anteriores y a explicar detalladamente la Escritura, exenta de dudas, que procede del Señor del universo" (CORTÉs, El Corán).

49 Una explicación más detallada sobre esta cuestión, sobre la traducción del término "patrañas" como"leyendas"y sobre cómo las fuentes islámicas conocidas como Las circunstancias de la revelación explican que Mahoma tuvo contacto con esclavos cristianos a los que escuchaba leer sus Escrituras en sus lenguas, puede verse: Pilar GonZÁLEz CASADO, "La caída del ángel, huella cristiana en el Corán", Revista española de teología (Mayo-Agosto 2016) vol. 76, Cuad. 2, Universidad San Dámaso, Madrid, 324-329. 